\title{
Labour Commodification, Differentiation and Marginalisation of the Peasantry in Sella Limba (Sierra Leone) from 1950 to the Present
}

\section{Authors:}

Augustin Palliere : Comparative Agriculture and Agricultural Development Research Unit, UMR PRODIG, 2 rue La Valette, 75005 Paris, France

Jean-Luc Paul : Département pluridisciplinaire, Institut des Mondes Africains (IMAf), Centre Malher, 9, rue Malher, 75004 Paris, France

Hubert Cochet : Comparative Agriculture and Agricultural Development Research Unit, UMR PRODIG, University Paris-Saclay, AgroParisTech, 16 rue Claude Bernard, 75005 Paris, France

\begin{abstract}
In Sierra Leone, migration to diamond fields and the development of cash crops have contributed to the increasing integration of the peasantry in the national and global economy. Based on the study of a small northern chiefdom, Sella Limba, we describe how the labour commodification has led to the perversion of 'traditional' social relations based on anteriority, and to the break-up of large domestic groups into smaller, more precarious ones. At the same time, manual agriculture has been marginalised by massive cheap rice imports, and remained very low in capital intensity. In this context, we show how low labour productivity curtails opportunities for long term social and economic differentiation. Farmers combine 'modern' and 'traditional' social relations, developing hybrid accumulation strategies that are sometimes close to mere survival.
\end{abstract}

Keywords: labour commodification; Sierra Leone; differentiation; labour productivity; children fosterage

\section{Introduction}

The 'modernisation' of African rural societies refers often, in the scientific literature, to dynamics resulting from the economic integration of the peasantries and the commodification 
of social relations: development of cash crops, monetisation of economy, breakdown of lineage structures, development of economic migrations and schooling of children, among others. Differentiation within and general marginalization are complementary critical perspectives of the same process at two scales of analysis. Bernstein (2010), in Class Dynamics of Agrarian Change, defends the idea that, with the commodification of farm produce, peasants who have become 'small producers of goods' are subjected to 'class' differentiation. Mazoyer and Roudard (2006), in A History of World Agriculture, focus on the marginalization of the less well equipped sub-Saharan agricultures facing the competition on the global market with much more competitive ones. While in certain regions the precocious development of exported cash crop led to rapid differentiation within the peasantry, in others the picture is dominated by a global marginalisation.

At first sight, the Northern Province of Sierra Leone, considered as the poorest in the country (Gomez y Paloma et al. 2012), exemplifies the latter situation. Cocoa, which is the first exported agricultural produce, has never been developed as it has been in the Southern Province. From the 1950s onwards, diamond mining in the Eastern Province led to important labour migrations (Swindell 1974). The development of the mining sector paved the way for a national subsistence products market commodification (Riddell 1970). Even the Northern peasants were at the time producing rice which is the main staple in Sierra Leone, as well as other foodstuffs to the diamond districts which were undergoing strong demographic growth. But, the political choice has been made to support the mining sector to the detriment of the peasant agriculture (Richards 1996). In particular, since the 70's, local farmers have suffered from the decreasing producer price due to the competition with massive cheap import of rice. While rice has continued to be cropped for subsistence purpose, labour intensive cash crops such as tobacco and chilli pepper have become the main source of cash income. But the labour productivity has remained low, and even decreased. No accumulation process in more productive techniques has been possible and they have remained exclusively manual. Not only hoes and cutlass represent all the available tools in the region but even small rural processing machines which one may observe in many sub-Saharan regions such as rice hullers or palm oil press are inexistent in the Northern Sierra Leone. In the context of such a marginalised region where peasants were kept in a state of material poverty and could not accumulate capital, is commodification, as predicted by Bernstein, synonymous with longlasting economic and social differentiation within the peasantry? 
In this article, we discuss the issue of differentiation giving a special attention to the labour commodification process. Commodification is often seen primarily as the monetisation of farm produce and the development of cash crops. However, we show how, in a very labour intensive agriculture, the control of labour force, and potentially of labourers, in and out of the domestic sphere, appears to be a crucial element in considering differentiation within a marginalized peasantry. Following Meillassoux (1981), the labour commodification is considered here as the emergence of modern form of labour force as discrete quantities of labour (days, hours, piecework) that can circulate as a commodity independently from the rest of the social life. Labour force is then contrasting with 'labour energy' which can only circulate in life-time cycles between generations in the domestic sphere or through slavery (Meillassoux 1991).

After having briefly introduced our materials and method, we will trace the emergence of the labour force two to three generations back, reconstituting the functioning of the large domestic groups within which labour energy and subsistence were circulating under the authority of the elders. The labour commodification has been historically interrelated with important changes in domestic relations and in farming practices. One of the most important trends that we will have to describe is the breakdown of the large domestic groups into much smaller, and more precarious, ones. Nowadays, most labour exchanges between domestic groups and individuals go through 'labour gangs' (Richards 1983). We will analyse the dual role that this institution is playing with regards to labour commodification: on one hand, it offers the possibility of transforming the labour force into work days that can be monetized; on the other hand, its complex and deeply socially embedded rules curtail the complete commodification of the domestic labour force. We will figure out how the transfer of labour force through labour gangs explains a great deal of the economic disparity among domestic groups. But we will then question why such disparities do not result in capital accumulation and long lasting differentiation process, at least in classic terms. That will lead us finally to analyse the massive child fosterage that prevails nowadays in rural Sierra Leone as a modern form of labour energy accumulation strategy.

\section{Materials and Methods}

Our approach of labour commodification specifically, and of changing social relations generally, brings together two complementary French system perspectives. A crucial 
contribution of the French Marxist anthropology and of Meillassoux in particular (1973) is the basic contention that the link between social relations of production and the social relations of reproduction is a key element in analysing the social organization of the African peasantries. The former ensure the short-term functioning of the domestic group from an agricultural cycle to another, the latter its long-term perpetuation from one generation to another. Their link defines a 'social system' (Paul 2003)'.

Meillassoux's perspective is broad, he's concerned about African peasantries as supposedly kinship based societies. Our analysis is based on a specific rural territory that must be understood in its agro-ecological and socio-economical interrelated aspects. The concept of 'système agraire' or agrarian system (Cochet 2015) embraces those aspects but more importantly is designed to identify in which conditions the system may develop or rather a crisis may occur. In this view, piecing together modes of exploitation of an environment, social relations of production, conditions of integration into the global market etc. into an agrarian system and a specific social system is a heuristic method. We have characterized how the systems were historically functioning precisely to figure out why it is no longer functioning.

In this paper we are chiefly concerned with the analysis on the scale of the domestic group defined basically as the group of individuals that are working together at least on a single plot of farm. They are sharing the produce together, least a part of it. A more precise definition of their functioning is part of our historical analysis. Indeed, we will see that the large domestic groups that prevailed two to three generations ago were having very different economic and demographic characteristics compared to the modern ones. Current disparities and the potential differentiation process are analysed through measures of the economic results at the domestic group's level. We will distinguish Value Added and Farm Income. The former measures the creation of wealth during a production process, the latter corresponds to what, in the end, remains with the producer. It then reflects the conditions of access to production means (non-domestic labour force, land and capital) i.e. the forms of social appropriation of the product (Cochet 2015). In addition, we will distinguish the simple reproduction of the

\footnotetext{
${ }^{1}$ The Meillassoux's seminal book of 1973 raised long-lasting debate among anthropologist that refer themselves to Marxism: were lineage societies class divided? (Rey 1979, among others). This debate is beyond the scope of this paper and the important point in our perspective is that the formulation of a model (whether one labels it 'social system' or 'mode of production') is heuristic and should enlighten specific historical configurations.
} 
domestic group from one agricultural cycle to another (i.e. the part of the income that allows the exact reproduction of the unit in the way it functions socially and technically), from the enlarged reproduction (the surplus income).

The studied area is the Sella Limba, a landlocked but relatively densely populated Chiefdom of the Northern Province. It is about $400 \mathrm{~km}^{2}$ and has a population of 52579 inhabitants according to the last census (2004), then the population density is above $130 \mathrm{inhab} / \mathrm{km}^{2}$ compared to the national average of $70 \mathrm{inhab} / \mathrm{km}^{2}$. The settlement is dispersed in small villages averaging 284 inhabitants. The Chiefdom headquarters, Kamakwie, is approximately one day truck journey from Freetown. The climate is tropical humid (annual rainfall about $1800 \mathrm{~mm}$ ) and the landscape is hilly with an alternation of rain-fed lands and seasonally flooded swamps.

Most of the historical sources consist of life stories of Sella Limba peasants on a one-toone conversations (304) with peasants ( $27 \%$ of women) of various generations. This covered 75 different villages where several field surveys were conducted between March 2007 and December 2011. Three main topics were discussed: landscape and agricultural practices evolution, work organisation at the domestic and village level and generational and matrimonial social relations. Other sources (travel narratives, colonial archives, and aerial photographs) were used to analyse deeper historical heritages or to cross-reference oral testimonies.

This economic analysis at the domestic group level is based on 58 in-depth case studies conducted in 21 different villages between 2010 and 2011. The validity of the results is grounded on the sampling of the domestic groups analysed. Because unequal forms of labour force exchanges between domestic groups has appeared determinant to their potential economic differentiation, case studies were achieved both with 'transferee', through purchase or other means, and 'transferor' of work days. It soon appeared that differences in economic and social status within domestic groups and importance of the individual economic activities required interviewing strictly all active members of each domestic group. As a result the domestic group case studies represent a corpus of more than 200 interviews with people of various age and sex.

\section{Commodification of Labour Force in Sella Limba since 1950}

\subsection{Labour Energy and Subsistence Flow Within the Domestic Group in the}




\section{First Half of the 20th Century}

In 1930, with more than 30 inhabitants per $\mathrm{km}^{2}$ (McCulloch 1950, 49), Sella Limba was already densely populated. Dense coppices regrowth made of fast-growing trees, prevailed at the time in the hilly landscape. Slash-and-burn was the main mode of exploitation of the environment. The method consisted of first clearing with axe and cutlass and then leaving the vegetation to dry out and burning it during the hottest period of the year. At the beginning of the rainy season (June), rice associated with numerous crops, was broadcast while the soil was superficially scratched with a narrow hoe. Women were then in charge of weeding and men of building wooden barriers all around the plot. Harvesting went from the end of the rainy season (October) to the beginning of the dry season (December). The following year, groundnut and fonio (Digitaria exilis) were cultivated on a portion of the plot. Fertility reproduction was then ensured by a regrowth of 7 to 10 years.

Each village (meti) included two to three kuru kuru (literally the circle of houses) gathering each from 10 and up to 20 people of working age. At the head of such a large domestic group was an elderly man whom our interviewees referred to as the 'father', the 'chief' or the 'elder' ${ }^{2}$ (mayon ma, literally the first). Each year, he pointed out the location of the 'big farm' (tembuy). All the men and women of the domestic group cultivated that land, and the paddy harvested was placed in wooden boxes, under the strict control of the elder who was in charge of conserving the seeds and distributing the paddy for the everyday domestic consumption. The paddy was entrusted to the elder women who had a 'cooking pot' (somba). They supervised the daily preparation of food and shared the cooked rice among the individuals under their responsibility.

The testimonies of the older Sella Limba peasants describe the tensions within the large domestic groups, leading eventually to their segmentation. But only married men who had their own tools and seeds, and who were able to lead a good number of able bodied individuals could consider founding a new settlement at the margins of the village, or a new domestic group within it. A compromise consisted in entrusting some members of the domestic group with a 'small farm' (hutolo) adjacent to the big one. The produce of the former, like that of second-year fonio and groundnut plots, did not fill the elder's box but remained under the control of the women who managed their cooking pots. Nonetheless,

2 We will then keep this expression by opposite to the juniors, elder / juniors representing an institutionalization of the relation between the older / younger member of a given group. 
'small farms' were always contiguous with the 'big farm', and a single burn was carried out when deemed opportune by the elder. As a result, the working calendar of the juniors remained constrained by the work in the 'big farm' under the elder's control.

The elder's control over the juniors' labour energy at the agricultural cycle level, translated into the strict control of the matrimonial relations at the level of the life cycle (as underlined by Chauveau and Richards 2008). Sella Limba society is patrilineal and virilocal: the elders and the elder women monitored the flow of girls between villages and procured spouses for their sons. They usually came from 'matrimonial areas' (Meillassoux 1975, 73) composed of several neighbouring villages. All testimonies attest that young men married late at the time. Girls, on the contrary, went very young to live with the domestic group of their husband-tobe. Once there, they worked for many years under the authority of their mother-in-law before having their own 'cooking pot'. The 'patience' of the juniors (men as well as women) as an expression of their 'respect' for the elders is always described as a lost virtue by the oldest witnesses.

Pre-colonial societies in the region is often described as connected to coastal merchants through long distance trade and divided between landlords and slaves (Peters 2006). Grace (1975) explained how the British colonial masters allow the former to maintain their control over the latter, even long after the late abolition of the slavery in 1928. But, according to the sources available, it seems that the Sella Limba chiefdom has a rather different social background. Indeed, it has remained at the edge of the famous warlords' realms ${ }^{3}$ and outside the corresponding main trade routes ${ }^{4}$. In the few sources where it is mentioned (Laing 1825: 358; Finnegan 1965: 17; Grace 1975 : 176), the Sella Limba chiefdom is depicted as a target for slave raids and not as a "big man" location. This is consistent with the fact that, on the eve of abolition in 1928, the British intelligence services report master's complains about their run-away slaves settled in Sella Limba ${ }^{5}$.

The people of Sella Limba did not live in self-sufficiency for all that. During the first decades of the British protectorate decreed in 1896, Sella Limba remained isolated, compared to the regions near the trading posts of the river mouths in the North or along the railway

\footnotetext{
${ }^{3}$ Limba Sella are located at the edge of the 3 main commercial and political entities of the late XIXth century described by Finnegan (1965: 16):Bumban (under Suluku rule), Bafodea (Sumang) and Tonko (Bombalai). None of these famous chiefs name is evocative for Sella Limba people.

${ }^{4}$ The "FutaScarcies" route on the North and the "Falaba" route on the South (Howard 1977).

${ }^{5}$ Intelligence Diaries Karene District 1918-1927 consulted at the National Archive, Fourrah Bay College, Freetown.
} 
completed in 1907 (Riddell 1970; Deveneaux 1973; Sibanda 1979; Alie 1990).

The payment in cash of the hut tax to the protectorate authority through the so-called 'native administration' forced peasants to enter cash economy. Palm kernel was the main agricultural produce sold by Sierra Leonean peasants and the main source of revenue for the protectorate. The closest trading post was located around 60 miles away and the distance had to be walked on foot. Although the journey was undertaken by the junior men of the domestic group, cash incomes remained under the elder's control. Up until the beginning of the 1950s, it seems that the traditional social system escaped the radical involutions affecting the other regions that were more exposed to the modernisation process.

The forced integration of the peasantry of Sella Limba into the global economy, in any case, remained low: the domestic group produced almost everything for its subsistence, the largest portion of the labour energy was dedicated to food production, and only a marginal portion of the produce was traded. As such, the 'big farm' under the elder's control absorbed almost all the domestic labour energy, while almost all the subsistence flowed in the opposite direction, from the elder's box to the elderly women's cooking pot.

In this domestic economy, agricultural production only had a subsistence value likely to be converted into human energy that is feeding the working-age members of the group and producing the producers-to-be. This conversion took place within the constraining framework of the social system reproduction. Demographic imbalances between productive and unproductive members were resolved by child fosterage. It was carried out at first within the domestic group between the elder women responsible of the cooking pots, which are the paternal grandmothers (nanda) who were responsible for feeding the offspring of their daughters-in-law. It was also common for a maternal grandmother to bring up part of the offspring of her married daughter. In this case, child left his/her father's domestic group, and even village, to join that of his/her maternal uncle ( $s i s a)$. This transfer might be temporary but was often permanent. Today still, in the Sella Limba villages, patrilineal lineages recognized as founders (lasiri lineages) mix with more or less recent lineages, identified as the perpetual maternal nephews (thahine lineages) of the former, who have roots in the villages of the matrimonial area.

Up until then, labour flow had not yet taken on its modern form of labour force, i.e. discrete quantities of labour exchanged independently from the rest of social life. It is through virilocal marriage and child fosterage that individuals, in their social entirety, were integrated 
into the group that was going to benefit from their current or future productive capacities.

\subsection{From Domestic Swidden-Rice 'Big Farm' to Chili Pepper Individual Plots:} the Break-Up of the Large Domestic Group

In the 1950s, the diamond sector experienced spectacular development in the Eastern Province. The manual extraction of alluvial diamonds, which had first been forbidden, became authorised in 1956 (Zack-Williams 1982). Exactly at the same period, during the dry season 1955-56, the colonial order is seriously upset in the Northern chiefdoms by a wide peasant riot against the burden of the forced labour and the taxes to the benefit of the paramount chief (Rashid 2009). All old enough Limba men remember, the Balla Kinto strike' named after the local leader of the movement, and most have actively participated. They describe it as a rebellion of the youth against the Paramount Chief and his close relatives. The ending colonial power was quick to accept the demands of the Northerner peasants (Sierra Leone Gouvernment 1956). This political event marked a shift in the way the peasantry was to be exploited at a national scale. The extraction of agricultural produces like palm-kernel, through taxation, implied a strict control of the people that relied on the local despotism of the Paramount Chiefs. On the contrary, regular procurement of labour force to the mining sector implied to allow the mobility of the labour force.

Indeed, alluvial mining is not a capital intensive industry and requires a considerable unskilled labour force. For young men, even far from the diamond districts like those of Sella Limba, this was a new opportunity: their work acquired an exchange value independent from the domestic cycle. But to realize this value they had to join the mining districts far from their native villages and to break away from the lineage. Up until the 1990s when the civil war put an end to these migrations, around half of each sibship left the villages, most often for the diamond mining districts. Miners' daily wages barely exceeded the minimum required for the simple reproduction of the labour force on a daily basis. Junior members of the domestic groups who fled away to the mines aspired to emancipation more than to improving their material living conditions.

On their side, the elders could not accept losing the productive individuals they had 'produced' and whose presence within the domestic group was needed for its functioning - as well as for reproducing the social system as a whole. Many accounts testify to the multiplication of tensions between the generations. This is exemplified by many juniors 
leaving 'without even saying goodbye' as well as reports of the use of witchcraft by the elders against the juniors. Actually, the elders themselves took part in the dismantling of the former large domestic group by selling part of the domestic rice. The development of the mining sector generated high demand for foodstuff (Levi 1975; Richards 1996, 51) facilitated by the construction of the Makeni-Freetown highway in 1956 and later the Makeni-Koidu section. Traders, in search of rice to resell in the diamond districts, offered new manufactured products to villagers. This is the time when, for example, corrugated iron started to be used for respectable elders' houses. Then, as labour force, subsistence produces also acquired an exchange value.

The double flow of subsistence and labour energy at the level of the domestic group was partly diverted from the domestic reproduction lifetime cycles towards the market economy. The human energy invested in the producers' production was therefore largely diverted to the benefit of the mining sector.

Swamp rice cropping was adopted during the same period by Sella Limba peasants and swamps appeared partially cleared and exploited regularly in the 1958-1960 aerial photographs of the region ${ }^{6}$. This innovation process neither resulted from a demographic pressure on land nor from a decisive technological breakthrough. Indeed, swamp cropping has been adopted in the whole region despite an uneven population density and testimonies attest that the agricultural technologies (tools, rice varieties, tillage practices...) that allowed the swamp development was known and applied in neighbouring regions long before the $50 \mathrm{~s}$. To explain why swamp cropping has been adopted during this decade, peasants who took part in or witnessed these changes mentioned the opportunities offered by the emergence of the foodstuff market. A new compromise was reached within the domestic groups. In exchange for the labour supplied on the 'big farm', the elders offered the juniors the possibility to cultivate a swamp plot in their own name, often together with their maternal sibship. After the broadcasting period in the 'big farm', the young labourers went down to the swamps to plough their own plot using a new type of large hoe, and then to transplant the rice. These operations had to be carried out rapidly to align with the plot flooding. This new constraint was partly met by organising the youth into labour gangs (kune) in which labour force is exchanged among members on a daily basis. Swamp rice was harvested after the swidden

\footnotetext{
${ }^{6}$ Aerial photographs number 33/SL/6 et 33/SL/7 available at the Ministry of Land and Mines, New England, Freetown.
} 
rice. Part of it could be used not as subsistence but to purchase manufactured goods like prestigious imported clothes; another portion enabled the elder women to have at their disposal their own reserve for their cooking pots, independently of the elder's box. The spatial disconnection between the 'big farm' of the elder and the small swamp plots of the juniors allowed a more autonomous work organisation in the benefit of the latter. As such, the development of both rice marketing and swamp cropping techniques resulted in significant emancipation of the juniors and, concomitantly in relative empowerment of the different cooking pots within the whole domestic group.

Swamp cropping also represented radically new farming practices. Rice production no longer relied on the relatively long spontaneous regrowth between two crop cycles. However, it depended on the progressive development of the cultivated plot which included clearing, removing stumps, widening, draining, levelling etc. Those who made a significant labour investment de facto appropriated the land. This appropriation initiated the break-up process ${ }^{7}$ of the large domestic groups. As from now on they had at their disposal their own seed stocks and their own land, the maternal sibship took more systematically advantage of the death of the elder to reject collateral descent. Refusing to be under the authority of a younger brother of the deceased, they constituted new autonomous groups. In the middle term, this led to the creation of many smaller units for which the balance between the production and the reproduction (production of producers) has become increasingly delicate compared to the quasi-autonomous large domestic groups of the previous generations.

This emerging food commodity national market accelerated conversion of peasants into petty commodity producers and their integration into a national economy based on mining industry. These petty commodity producers were sacrificed in 1970's by an assumed policy of massive imports of cheap Asian rice, on which miners' wages were to be spent (Richards 1996, 51). Northern Sierra Leone and Sella Limba in particular were considered suitable for tobacco cropping and in late 1973 a local subsidiary of the British American Tobacco (BAT)was given a legal monopoly over tobacco leaves production and marketing in the region $^{8}$. BAT imposed an integrated cultivation model that involved procuring synthetic

7 Here we differentiate between segmentation on the one hand, which is a structural process of the traditional social system and which constitutes a means to resolve internal contradictions, and break-up on the other, a historical tendency described here and observed by many authors in the region (Binder 1989; Leach 1994; Delarue 2007).

${ }^{8}$ The details about the BAT - Government of Sierra Leone deal can be traced back thanks to the internal memorandum of the company available on the website "Legacy Tobacco Documents Library": 
fertilizers offered by the company whereby farmers had to apply strict cropping and packaging prescriptions. One of the most constraining requirements was to remove completely all stumps from the tobacco plot. The BAT cropping system represented a dramatic change in the way fertility was managed. Fertility no longer relied on spontaneous regrowth but on the input of fertilizers. Where tobacco cropping has been practiced on a large scale, slash-and-burn farming has no longer been possible, even long after BAT has withdrawn. Moreover, tobacco cropping was in competition with rice cropping. To compensate for the subsistence gap the tobacco cropping induced at the domestic level, BAT soon started to provide to the contracted producers imported rice bags, repaid at the harvest. From 1975 onwards, BAT contracted a large number of farmers, with huge and durable consequences both on the agro-ecological environment and on local economy. Asian imported rice held an important place in the local market, a situation that would never change.

The tobacco period in Sella Limba (1975-1996) was characterised by the intensification of the economic integration of the peasantry, and by the rapid monetisation of its economy. Tobacco was a strictly commercial crop and its large development in the 70's-80's has contributed to establish a direct relation, within the domestic sphere, between a work day and its monetary value. Work day began to be exchanged for cash or for rice within the villages. The youth of the time still mention today how annoyed they were, about having to work so that the elder could become wealthier at their expense. Conversely, the elders were for the first time able to get labourers only when needed in their farms without having to support them during the rest of the year. At the village level and even among the domestic sphere, discrete quantity of labour force acquired a value independently from the rest of the social life.

In March 1991, the Revolutionary United Front (RUF) launched from the neighbouring Liberia an armed struggle in Kailahun and Pujehun Districts engaging a civil war that lasted until January 2002. The actual motivation of the RUF and the deep causes of the prolonged violence have been the object of controversial academic debates, with implication for development policy. Let apart Malthusian apocalyptic views (Kaplan 1996), the academic debate has focused on the 'greed not grievance' argument suggesting that both rebels of the RUF and others armed group were simply motivated by resources appropriation (Collier 2001). all the war would be about diamond. But if diamond mining has fuelled the war, the 
young conscripts of the RUF (and of other armed group implied in the violence) voices, collected by Peters (2006), underlined the particularly unfair social order in rural areas of the Eastern parts of the country. The crisis of the patrimonialist state (Richards 1996) made the situation explosive. Long lasting class cleavage between landlord and slaves or native and strangers, re-emerged.

We depicted a slightly different social background in Sella Limba. But it does not imply that the social system involution and the agrarian crisis have nothing to do with the civil war that broke out on the other side of the country. The Sella Limba has been directly affected by the civil war after 1996 when the RUF attacked the chiefdom for the first time. From 1998, the RUF / AFRC has controlled Kamakwie and its region, imposing heavy contribution of the population for the war effort. The RUF recruited little among the rural youth of Sella Limba. But all those who were not in position to marry and work for themselves and who have fled to the diamond districts 'without even saying goodbye' have increased the number of the poor and 'hyper-mobile' youth (Chauveau and Richards 2008) circulating between the rural slums of the diamonds mining areas, the villages where, as strangers, they were condemned to work for bare subsistence and underpaid petty jobs in Freetown.

The propagation of the civil war in the region under study, caused the closure of the tobacco industry, and the slowing down of commercial activities. The movement of integration of the Sella Limba agricultural economy into the market, marked time or even went backwards. Today, the chili pepper has replaced tobacco as the main commercial crop, and households continue to buy almost half of the rice they consume from the market. Tradable labour force, in the form of work days being purchased and sold between farmers, is still developing.

The increase in population density, associated with the compulsory uprooting of wooded regrowth for growing tobacco, led to the disappearance of slash-and-burn farming. In order to confront the sudden degradation of agro-ecological conditions, peasants adopted the ridging technique which involved the burying of the vegetal biomass. The advantage is that this limits the weed pressure while at the same time concentrating the upper soil horizon it makes available most of the decomposing organic matter. Nowadays, swamp lands are ridged every year before transplanting the rice. The rain-fed lands are ridged every four years before transplanting the chilli pepper. The mode of exploitation of the environment is now based on this intensive tillage practice. In addition, more frequent and intense weeding sessions have 
become necessary for maintaining the plots during the rainy season.

For the last fifty years, Sella Limba peasants has adopted new rice varieties, developed new tools (which nonetheless remain manual), invented new rotations and associations. However daily gross farm labour productivity ${ }^{9}$ has remained at very low level, if not declined. Based on the data collected, we estimate that labour productivity is between $€ 2.7$ and $€ 3.6$ by work day on the farm ${ }^{10,11}$. Such a low production level barely exceeds the nutritional needs required for the reproduction of the domestic group.

It is relevant to compare daily gross farm labour productivity with daily wages that labourers may expect in urban or mining sector. Many youth are selling their labour to "boss men" of small-scale gold sites. Wages are maintained at between $€ 1.8$ and $€ 2.7$ per work day, i.e. less than the daily gross farm labour productivity rate ${ }^{12}$. Unskilled labourers' daily wages in Freetown may be even lower. As such, while off-farm activities may supplement, during the off-peak dry season in particular, the low agricultural incomes that are always subjected to unforeseeable weather and market price variations, urban or mining sector jobs do not represent a desirable alternative for the peasantry. Despite the dramatic increase in gold price following the 2007-08 global financial crisis, very few Sella Limba peasants leave their farms permanently.

9 Ratio between the quantity of produce obtained and the number of work days invested in cultivation.

10 Sums are given in Euro for easier understanding. In 2011, during the field research period, 1 Euro equalled 5500 Leones on average.

11 This data, which dates from 2011, is the result of the analysis of agricultural practices on the scale of the cropping systems based on the decomposition of the landscape into agro-ecological facets, and of a zoning of the region under study(on these concepts see Cochet 2015). Although this analysis goes beyond the scope of this document, it must be noted that quantifying daily productivity levels on the scale of the cropping systems, includes produce that have been sold as well as used for home consumption.

12These daily wages, in 2011, corresponded to between $2,8 \mathrm{~kg}$ and $4,3 \mathrm{~kg}$ of rice at the market price. It is striking that, on the eve of WWII, unskilled workers were striking to obtain minimum daily wages of about 1 shilling, corresponding to around $5 \mathrm{~kg}$ of rice at the tariff of the time (circular on Rates of unskilled labour $\mathrm{n}^{\circ} 18 / \mathrm{D} / 9 / 31$ of 26 May 1938). Then unskilled labourers' real wages, probably with labour productivity of the less well equiped agricultural sector, has historically declined in Sierra Leone. 


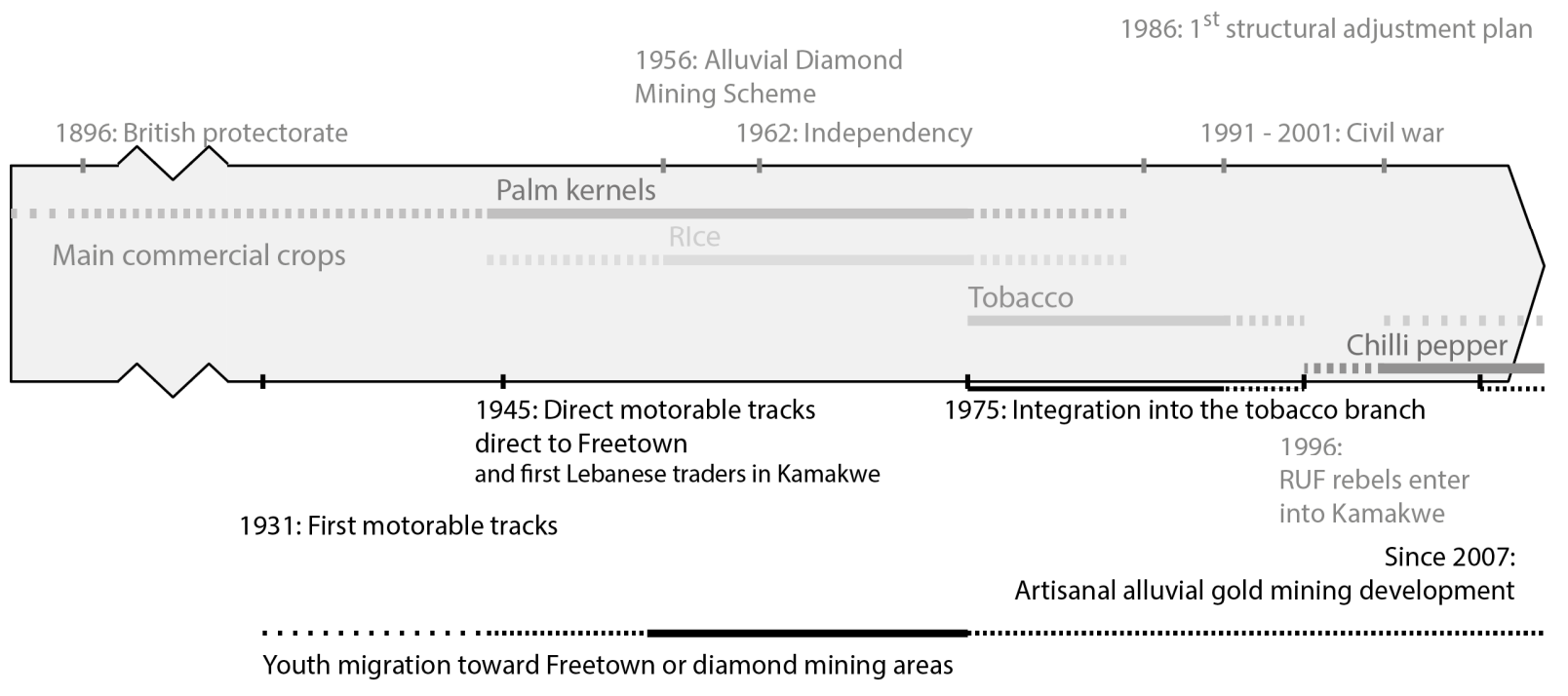

Figure 1: Chronology of the economic integration of Sella Limba into the national and international market

4 Labour gangs: Institutionalising the Incomplete Commodification of the Labour Force

The integration, under variable but always more adverse conditions, of the Sella Limba peasantry into the global economy has resulted in the commodification of the domestic labour force. This dynamic has had huge agro-ecological, social and economic consequences. One of them has been the break-up of the large domestic groups into smaller and more precarious ones. They now gather most often 3 to 4 people of working age of both sexes, some only 2 and never more than 10. These groups are exchanging work days and the majority of these exchanges are institutionalised into labour gangs named kune. An analysis of the rules of this institution and the way these labour gangs are actually operating shows the incomplete and hybrid character of the commodification of the labour force.

Labour gang members keep repeating 'you work for me, I work for you' to highlight the reciprocity and solidarity among them. They say peer pressure and competitiveness is a source of emulation and more work is achieved by 10 persons in one day than by one person in ten days. This type of group is very common in West Africa. To take uncritically these local normative speeches about solidarity and productivity may conceal unequal labour force transfers between their members.

\subsection{How labour gangs work: exchange, purchase-sale or gift}

The contribution of each member of a labour gang is strictly accounted for. If each member 
of a 20-member gang benefits from five turns, each will get 100 work days on his farm. Each labourer carries out a specific number of 'portions' (bara) in a day, and the labour gang's leader is responsible for dividing these portions equitably. Delays and slapdash work are punished with fixed penalties. Under 14 years, an adolescent carries out half portions and, therefore, only benefits from the gang every second turn. These rules are concerned with breaking up precisely the work day of each gang's member. Then labour gangs are not only an expression of solidarity but a work organisation that enables the labour force commodification. It is indeed possible to sell one's turn in exchange for rice or money. When farmers decide to do so, it is always due to a lack of working capital. When a rice plot is ready to be broadcast but the seeds are lacking, one barters with a farmer in possession of extra seeds, a turn of kune with 20 members for 20 pans $^{13}$ of seeds (the equivalent of $€ 18.2$ ). Yet, the cost of one work day within labour gangs, less than $€ 1$, is less than the average daily agricultural productivity, which justifies the buyers' investment. Nevertheless, the latter must have enough working capital to buy 20 work days in one go, because a gang of 20 members cannot be divided. Labour gangs work in turns and these turns can be also sold to obtain food during gap in the rainy season. At that time, while everyone is focused on weeding their farm, the sale of a 20-member gang can feed 5 people with imported rice for about ten days.

In addition to direct purchases/sales of work days, another rule of the labour gangs leads to unequal transfers of work days between its members. A hearty meal must be offered to the labourers of the gang when working on one's farm. If a member is not capable to afford it, the gang will work only half day in the morning, getting through half the normal work. As such, due to lack of working capital, some gang members can barter entire work days for half work days.

Finally, gift of work days through a turn of the labour gang is not uncommon. Yet, such gift usually falls within long-lasting social relations. An elder may seek help from a junior who will give one of his labour gang turns. As it often happens, the latter will have been fed by the former earlier in his life. Later, at the harvest time those who have work are called to help again, and to take their share. In addition, even largest amount of money or rice has to be spent into the workers' meal, elders require important resources to really enjoy this gift.

\subsection{Sharing the available labour force within domestic group}

13 A pan (a plastic bucket) of paddy in Sella Limba weighed around 2,5 kg in 2011. 
Not only does labour gang make it possible to barter work days between domestic groups, it also makes it possible to share work days within them.

Spouses share their work time on their respective plots. However, a newly married young wife is in an unfavourable position since she will not only be required to do the most unrewarding chores, most of her labour gang's turns will benefit her husband and mother-inlaw. She will benefit little from her own labour force and her own plots will be of very small size. Years later, when her children are grown up, she will seek in turn a 'small wife' to marry her husband. The 'small wife' will replace her in the labour gang and do the most tedious chores. The first wife will then progressively increase the surface area of her crops and her autonomy within the group. But while the balance of power is unfavourable to a young wife, the threat to see her returning to their (often neighbouring) native village is permanent. Such a resignation, in the middle of the working season, could question the very survival of the domestic group. Then, even with junior wife, negotiations on this issue are still necessary as husband and elder women complain.

The sharing of the work time within the domestic group also takes place between generations. A young bachelor with five turns of a 20 member labour gang at his disposal will dedicate, without compromising, the first two to the plots of the group's head. Then he will have to help his mother to plough her parcel of groundnut and leaves the last turn of his labour gang to ridge his own parcel of chilli pepper.

Junior members of the domestic group sometimes take a risk in 'stealing' work days from the elders, by secretly selling a turn of their labour gang. As the young men take on more responsibilities, for instance when they get married and bring up their children, elders would normally let them enjoy an increasing portion of their labour force. As such, at the head of an important domestic group, an elderly man will have at his disposal one turn of labour gang from each one of his sons, who will be working autonomously with their wives or mothers the rest of the time. As such, the emergence of the smaller units take shape long before the death of the elder that will result inevitably in the breaking up of the domestic group.

Few generations ago, labour energy flow was confined inside the large domestic groups under the uncontested authority of the elder. Nowadays labour force flows have taken on the form of non-equivalent transfers through labour gangs, between individuals from different domestic groups. Yet, labour force commodification is curtailed through the embedding of their flows in intergenerational and gender social relations extending beyond agricultural 
cycles.

Nevertheless, the new forms of work organisation found in some villages are an indication of the commodification of social relations to come. Certain young men prefer to join smaller labour gangs (e.g. with only five members), in which more flexible rules are adopted, for example by eliminating the hearty meal altogether, or by replacing rice with a less costly staple food such as boiled cassava. With the possibility to mobilise a fewer number of labourers, they escape from the necessity of having considerable resources at their disposal. These small gangs generally escape from the elders' control.

\section{Economic and Social Differentiation of Domestic Groups in Sella Limba Today}

The break-up of large domestic groups into smaller ones goes hand in hand with the commodification of the labour force, albeit incomplete. But we do not observe any significant development of productive forces and the daily gross farm labour productivity has been, at best, stagnating. The domestic scale analysis of productive processes will show that economic disparities among the peasantry, even limited, relies on the plurality of labour transfers modalities.

\subsection{Simple vs Enlarged Reproduction: The Economy of Agricultural Production Processes in Sella Limba}

The value added and the farm income by labourer depends closely on the average surface area a labourer may work given the agricultural practices prevailing. The heaviest operations with the narrowest time slot are the hoe ridging and the manual weeding of the plots, between May and August. Under standard conditions ${ }^{14}$, we estimate that a labourer can cultivate annually 0,1 ha in swamps and 0,8 ha in rain-fed lands, for a gross product per labourer and per year in the region of $€ 460.6$. After deducting the value of the seeds (€65.8), we obtain a value added per labourer and per year of $€ 394.7$, the depreciation charges of the fixed capital - hoes and cutlass - being negligible. Deducting the token for the founding lineage elders who distribute land usufruct rights, as well as various gifts granted during harvest time, we

14All following results come from analysing 58 case studies conducted in Sella Limba. A complete description of the method and hypotheses required for economic calculations goes beyond the scope of this article(Cochet 2015). However, let us point out that, for each production/consumption unit, this article relies on the specific inventory of labourers and consumers, plots cultivated by each individual, and the origin and destination of the labour force being mobilised. VA and FI correspond to the valorisation, most often at retail market price, of all productions: crop rotation and crop association, crops that have been sold, consumed at home, given etc. 
figure out the farm income ( $€ 308.7)$, i.e. the share of the value added going to the producer. The quasi-totality of this farm income (92\%) is dedicated to supporting the members of the group (producers, pre- and post-producers) ${ }^{15}$. Today in Sella Limba, the average number of consumers ${ }^{16}$ per labourer is around 1.9 (i.e. 0.9 non-active/active labourers). This ratio varies considerably from one group to another, a key issue that will be discussed further below. As such, under the current (technical, economic and social) conditions, the average surplus per farm labourer is very low (about $€ 24.7$ ).

Then, the simple reproduction of the domestic groups is precarious (Figure 2).Indeed, this average situation does not take into account the many unforeseeable (climatic, economic, political, etc.) and morbidity (illness, accidents) factors affecting production and labourers. The slightest accident can, in the short term, threaten the survival of the domestic group. Under these conditions, the different forms of solidarity being forged within the peasantry do not appear as traditions preventing the dawn of the economic development but as a bare necessity. The significant gifts granted during harvest time represent the most visible form of solidarity. In this light, the precariousness of the modern rural life explains, as we will see, the coexistence of seemingly contradictory accumulation strategies.

15 An adult in Sella Limba nowadays consume annually about $126 \mathrm{~kg}$ of rice, $14 \mathrm{~kg}$ of palm oil, $18 \mathrm{~kg}$ of groundnut with shell, $90 \mathrm{~kg}$ of fresh cassava, $6 \mathrm{~kg}$ of dry pea and the equivalent of $€ 41.3$ of bought ingredients (fish, glutamate, salt, etc.). Regarding to the value of these subsistence produces, the essential needs (aside from medical care), such as clothing or hygiene products, have a negligible cost.

16 Weighted by consumer age ( 0,5 for children who do not yet take part in labour gangs, 1 for all others). This slightly rough weighting is inspired by the way the women who cook calculate rice rations for their hearth (in cups and half rice 'cups'ofabout $0,3 \mathrm{~kg}$ ). 


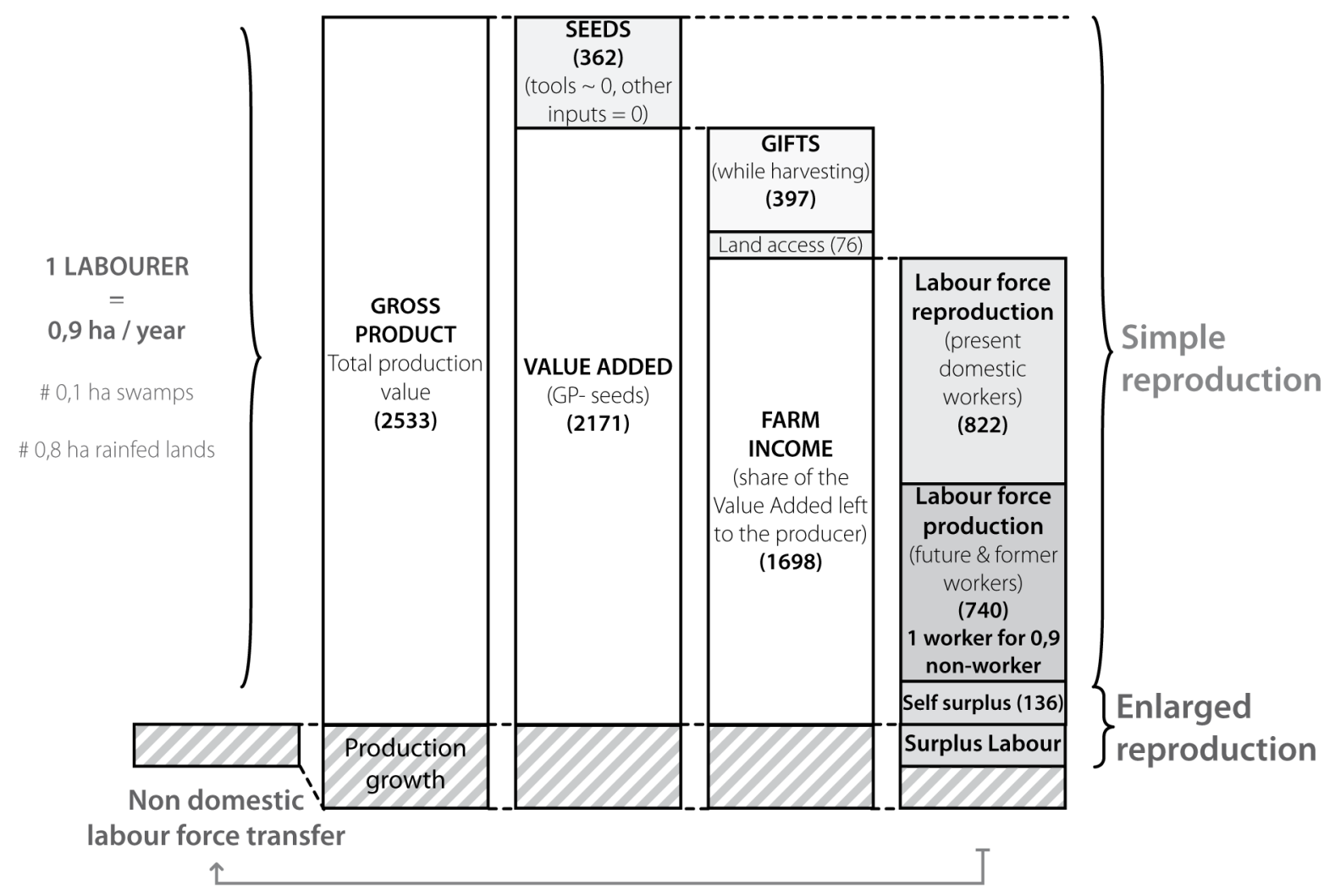

Figure 2: Simple reproduction and enlarged reproduction

This reasoning corresponds to domestic group employing solely domestic labour force on its own plots only. Yet, as seen previously, with the break-up of the large domestic groups in the last decades, the unequal transfers of work days via the labour gangs has become increasingly significant. In order to increase their surplus, farmers try to dedicate part of their income to obtain non domestic labour force, between May and August, when the opportunity cost of a work day is at its maximum.

For each cropping cycle, the resources injected into the production process to obtain non domestic labour force, come from the surplus obtained during the previous cropping cycle. Working capital (food-producing and monetary) is converted to surplus labour converted in turn to surplus wealth. As such, there is, in a classical view, a potential accumulation process. We will now try to assess the extent of this accumulation and its result in term of differentiation among the peasantry.

\subsection{Impact of Labour Force Flows Between Domestic Groups on Farm Income Differentiation}

The labour force flows between domestic groups through labour gangs, and its cost it 
corresponds either to the direct purchase of labour gang turns, or to the preparation of the compulsory meal. In 2011 , labour gangs cost $€ 0.9$ per labourer per day, and the meal was equivalent to $€ 0.4$ per labourer. The domestic groups with the highest working capital (rice or cash) dedicated up to $€ 272.7$ per year to labour capture between May and August. On the opposite side of the graph, other farmers lack resources at their disposal to host labourers on their farm, and sometimes have to sell one or several labour gangs' turns, with some making up to $€ 55$ during the same time slot.

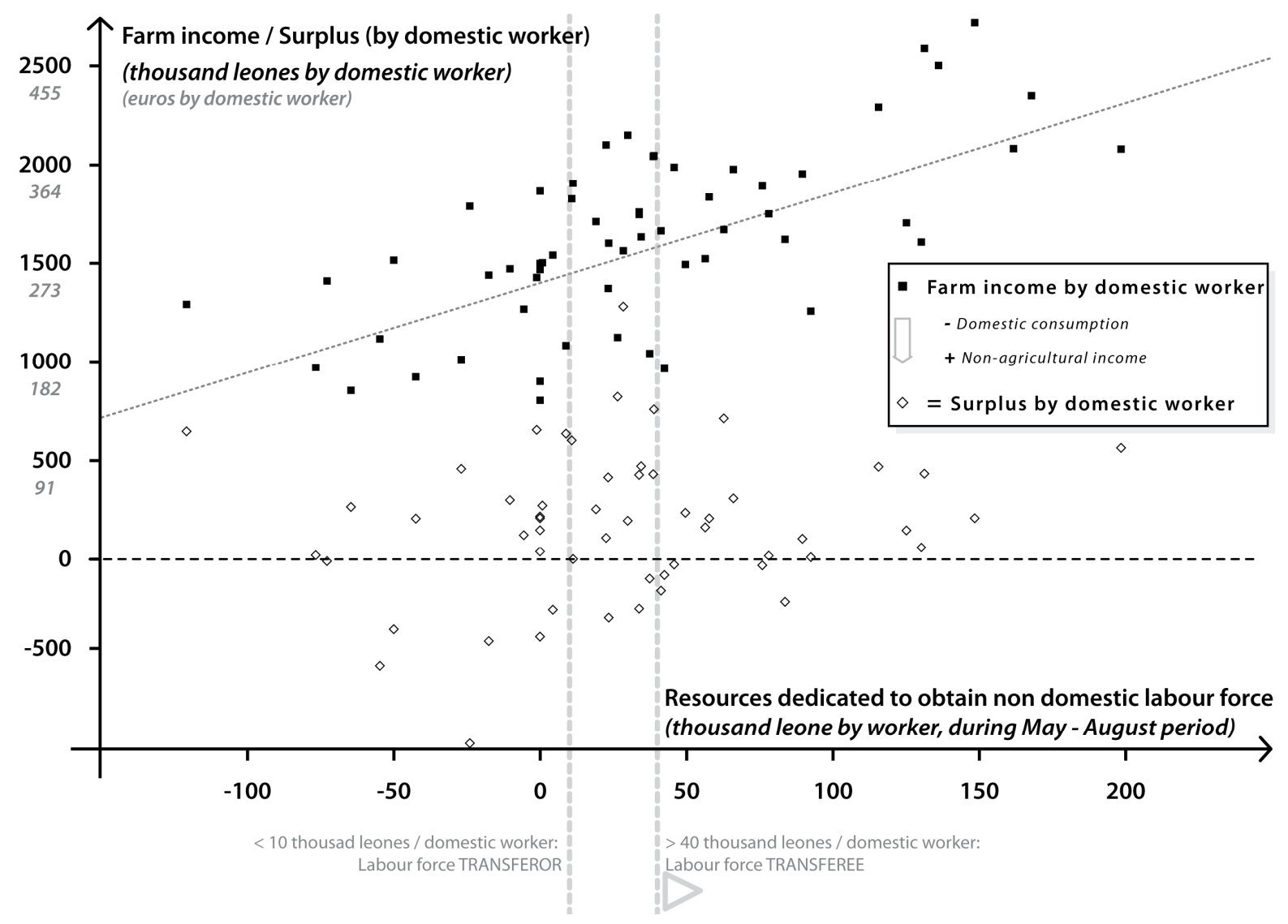

Figure 3: Farm income and surplus per domestic active person according to the resources dedicated per domestic active person for capturing labour force between May and August

Figure 3 indicates that the farm income per domestic worker (working age domestic group members) regularly increases with the quantity of non domestic labour force transferred in $^{17}$. The main part of this farm income, as seen previously, is used for subsistence (home consumption and purchase of food-producing items). When we subtract from the total farm income of the domestic group the minimum amount required for its subsistence according to

17Obviously, for the same level of expenses in acquiring labour force, we observe variations linked to slight differences in rotations, in access to different selling prices or, still, in balances between men and women within the units. 
the actual (not an average) number of its active and non-active members and then we add nonfarming income ${ }^{18}$, we obtain the 'surplus'.

Figure 3 shows firstly the general low level of surplus and secondly its non-correlation with the level of non domestic labour force obtained by transfer.

The general low level of surplus is consistent with the material poverty one can observe in the modern Sella Limba. There are units with a low (i.e. less than €40) or even negative surplus. For these units, the solidarity found in kinship and neighbouring networks can help them make it through an exceptionally difficult year. But when the gap between income and needs becomes structural, domestic groups tend to break up. In this case, wives divorce their husbands, taking their children with them to live in another home; children are sent to a wealthier maternal uncle and youths migrate to the mines or Freetown.

The average positive surplus is about $€ 60$ per active person per year. This is to be compared with consumption goods in modern rural Sierra Leone. A respectable man must be in possession of a" 4 rooms" house with corrugated sheet roof for an average cost of $€ 363.6$. In order to build such a house, most farmers enter tontines and save between 5 and 10 years for it. During a good year, a minority of farmers will also be able to purchase a goat (between $€ 18$ and $€ 36$ ) in which they rely in case of unexpected expenditure ${ }^{19}$. The wealthier groups with exceptionally few dependents per active person generate around $€ 135$ per active person per year. A Chinese manufactured 125cc-motorbike which is the common means of transportation in many African rural areas, is worth in Kamakwie more than $€ 900$ and remains out of the Sella-Limba farmers' reach.

Even for the wealthiest producers, the level of surplus does not make it possible to initiate a enlarged reproduction process with access to industrial inputs or motorisation. Firstly, the number of days captured remains marginal regarding to the domestic labour force engaged in the production process. Secondly, the daily gross farm labour productivity being very low, the total surplus labour value from the captured labour force represents only a small portion of the farm income of the wealthiest domestic groups. The labour force commodification has not resulted in the emergence of a class of petty rural capitalist class facing a class of peasants undergoing proletarianization. The big picture is rather a social and economic disintegration.

18Mainly wages from labour gangs selling and from manual placer gold mining during off-peak season of the year.

19 However, to accumulate in larger herds is considered risky: between 1996 and 2001 almost all the sheep and goats in Sella Limba have been looted by the Revolutionary United Front troops. 
The wealthiest domestic groups are struggling for their simple reproduction year after year andmost of the others somehow survive under ever deteriorating conditions.

\subsection{Short-Term Labour Force Capture or Labour Energy Accumulation: Hybrid}

\section{Strategies}

Let us then consider the second result. The surplus generated by domestic groups are low but the Figure 3 also shows that, contrary to the farm income, the surplus is not correlated to the quantity of resources involved in non domestic labour capture. Domestic groups with access to non domestic labour force do not generate a higher surplus than those transferring labour force out of their domestic group. This paradox results from the disparity between domestic groups regarding the ratio of mouths to feed per active person. On average, the consumer/active person ratio is 1.9. However, in certain case, it drops below 1.5 (for example a couple with two children) while in others it increases beyond 2.5 (corresponding to a couple with six children). These disparities do not result in the existence of various stages of the domestic unit development ${ }^{20}$. It results from the flow of children between domestic groups. As in many of the peasant societies of West-Africa, offspring are not systematically brought up by their actual progenitors or only by them (Goody 1982). A survey conducted with 148 adult women shows that out of 223 offspring that are still dependant on an adult (children and unmarried adolescents), 61 of them (27\%) were brought up in a unit other than that of their biological mothers. On the other hand, these 148 adult women are bringing up 72 children (i.e. $30 \%$ of the children supported by them) whom they did not give birth to ${ }^{21}$. As anywhere else in Sierra Leone (Bledsoe 1989), elderly women and maternal grandmothers in particular, are often the recipient of this flow. Children are often brought up by several women during their pre-productive lives, and feeding a child on a daily basis is not the only way to contribute to his upbringing. One can also supply the money and rice required for his initiation or contribute for the school fees.

Without excluding the affective dimension, elderly women describe explicitly the energy and resources dedicated to bringing up these children as an investment. When they complain

20As is the case of the Tchayanov's theory of peasant economy(1966 [1925]).

21This is a low estimate of this phenomenon, which corresponds to cases where children are changing residence. Between the cooking pots of the same residence unit, the flow of children is more discreet and also more reversible. On the other hand, these figures are consistent with the results of other surveys conducted in Sierra Leone. Among the Mende in the eastern part of the country, between 30 and $45 \%$ of the children are 'fostered'(Bledsoe 1989; Isaac and Conrad 1982). 
about children not having given 'news' since they left for Freetown, they blame them for not bringing them money, rice or clothes. Likewise, in Kryo English, a child who died prematurely or an adolescent who fled without 'saying goodbye' is said to be 'wasted', as one would have said for a lost crop or any other investment.

Then surplus income of the wealthiest groups is used not only for short-term labour force capture but also for bringing up children of pre-productive age; This is for long term investment in production of labour energy. The use of the latter is deferred - and therefore uncertain - but potentially possible over several years or even generations. We then speak of hybrid accumulation strategies which are basically the purchase of work days on one hand and the adoption of the future active persons on the other. These short and long term strategies are partly contradictory as they involve the consumption of a portion of the farm income 'eaten up' by unproductive children hence not available for the immediate purchase of work days. Actually the short term labour force capture and the generation of a surplus make possible the accumulation of rights on a labour energy in production and therefore to consolidate the precarious life of the domestic groups.

\subsection{The Current Permanence of Former Social Relations in Large Households}

In their discourse, the elders continue to give a lot of importance to the 'domestic unity', and they disapprove the ambition of the youth seeking emancipation which they always see as premature. As such, gathering many individuals under one's authority is still a sign of prosperity in the long term.

Globally, the break-up of the large domestic groups gave rise to smaller ones. But we observe diverse situations. The majority of domestic groups bring together 2 to 4 active persons, usually organised around a monogamous couple with one brother or child of working age. A few polygamous elderly men bring together, under their authority, 5 to 10 active persons. The latter units seem to reproduce social relations that prevailed fifty years ago. All active persons contribute to working on the plots of the elder. The latter redistributes food products via the elderly women of the group. However, each labourer has nowadays his own individual plots, with sizes varying according to his status and his own resources. Here we have seen how the labour gang institution enables the flow of labour force available within these complex domestic groups.

While individuals benefit from greater autonomy, how can we explain the persistence of 
such large domestic groups in the modern rural Sierra Leone? Figures 4 and 5 show that, proportionally to the number of domestic workers, the number of dependent children as well as the level of resources invested to acquire non domestic labour force, are more important for these units. Neither is a net supplier of children or labour force. They are, on the contrary, the main recipient of both the children and work day 'flows'.

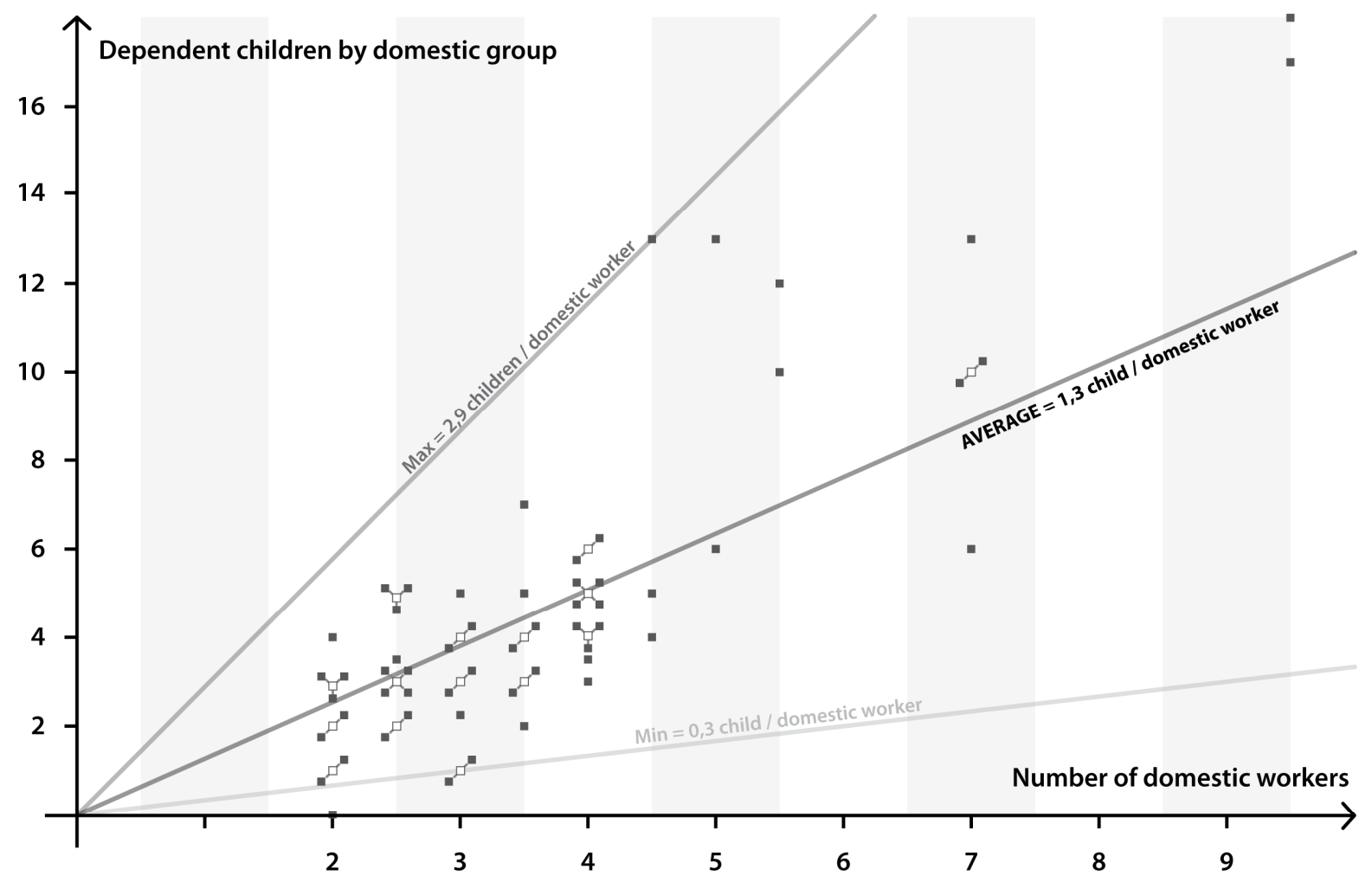

Each point ( $\square$ ) is a domestic group

; ;

Figure 4: Number of pre-productive dependent children according to the number of domestic workers (per domestic group) 


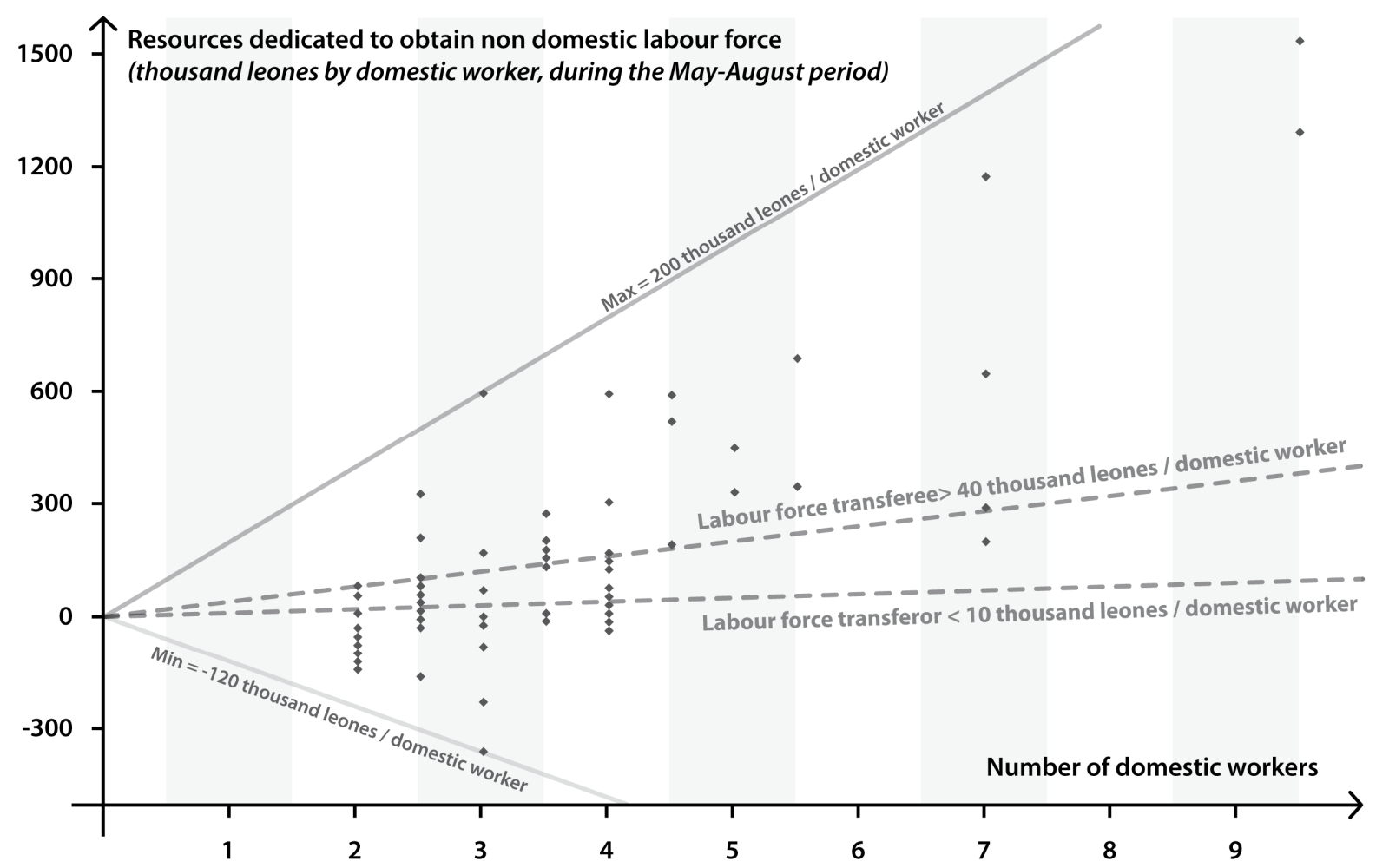

Figure 5: Resources dedicated to obtain non domestic labour force between May and August according to the number of domestic workers (per domestic group)

It is as if there was a kind of economy of scale. Due to labour gang rules, most of the labour force is not freely available in any form. As we have seen, it is socially unacceptable to buy one hour or one day of work. One needs to mobilise all the resources required for buying one labour gang and all its members as a whole ( $€ 18.2$ for example for one 20 -memberturn). As such, only domestic groups that gather the surplus of a large number of domestic workers are able to afford the cost. Smaller groups, even if they generate a small surplus, do not have this capacity. This reasoning is also applicable when adopting a child.

Gathering people relies on the elders' capacity to bring together a sufficient number of working age people under their authority, by activating social relations based on precedence, even if these are distorted and manipulated. However, these pseudo contemporary large domestic groups are always threatened of dispersion. For example, women pay attention to their children's future and young workers are often tempted to abandon the elders to emigrate to Freetown. Domestic unity, highly valued by elderly men, depends mainly on whether or not it is in the interest of the women and the youth to remain under their authority. This and basically depends on the harvests obtained every year. This is what the elders of Sella Limba emphasise when they repeat ' where there is no rice, there is no unity'. 


\section{Conclusion}

Labour productivity in Northern Sierra Leone's manual agricultures has remained low. Almost all the value added a worker is able to generate, either in the form of food or in the form of cash, is dedicated to the simple reproduction. In other words, farmers are working basically to ensure the simple subsistence of their domestic groups. Extra agriculture opportunities, like small scale gold mining, may improve farm income but do not constitute a viable way to make a living.

To capture extra domestic labour force is the only way to accumulate surplus income and to engage enlarged reproduction. Workdays are purchased when the opportunity cost is at its highest, between May and August. Farmers who sell workdays are looking for seeds they lack to plant their own plot or rice to feed their children. In these circumstances, they are not able to enjoy their own labour force. Extra-domestic labour force circulation is then a source of disparities and even a potential mechanism of "class differentiation" in the sense of Berstein (2010).

The institution of labour gang organizes the exchange of workdays between domestic groups. For each farming operation, a workday is normalized and correspond, to a certain quantity of work to be achieved. It can be expressed in monetary terms, even if it is often actually bartered for rice seeds. Once socially embedded, the labour force is now disconnected from the labour energy produced and reproduced over generations. Then, the labour gang appears as a driver of labour commodification. At the same time it is a strong regulatory institution that does not allow the full liberalization of the labour force exchanges. Because a gang of twenty cannot be divided, farming workdays can only be purchased in important quantity at once. To take full advantage of the labour gang work, large amount of money or rice have to be invested in the mid-day meal. Finally, only elders (men or women) at the head of the largest and the more stable domestic groups, governing important resources, may engage in this accumulation strategy.

More importantly, this short term labour force capture strategy is both completed and contradicted by long term labour energy accumulation strategy which involve fostering children, especially maternal nephews. At the end of the day, wealthiest and largest domestic groups consume most of the surplus production into bringing-up future workers.

But one does not accumulate people like capital: right over one's labour force cannot be 
transferred as easily as right over an asset like a land or a machine. Even if largest domestic groups tend to reproduce social relations of production that prevailed fifty years ago, they are not stable over the generations. Junior men and women may respect their elders because they are "taking care of them", but elders are also deeply involved in individual economic activities like cash crop farming, petty business or extra agricultural petty jobs. Large domestic groups are fragmented and none can survive the death of the elder at its head.

Finally, neither short term labour force purchase nor long term fostering of children constitue viable strategy of wealth accumulation Whilst important social and economical disparities may be observed among domestic groups, there still does not appear to be a discernable class system.

However, we observe new forms of labour force commodification. New labour gangs' rules that better fit youth constraints are adopted in certain villages (smaller groups, no costly meal to be prepared). In artisanal gold mining, teams of workers are paid by day by an unknown boss of urban extraction. A daily wage is therefore part of the routine of many young men in Sella Limba who are looking for extra income in gold mining sites. Even if resistance to it is to be expected, we may assume that wage labour freed from labour gangs constraining rules will progress within villages. Will this further step in labour commodification mark the dawn of a long-lasting class polarisation within the peasantry? If our analysis is correct, where these processes are taking place with no progression in labour productivity and under unfavourable market integration conditions, it is not synonymous of accumulation but of more precarious living conditions for individuals. Then, the few young farmers who are most prosperous will not be able to sustainably pursue a short-term productive and individualistic strategy. It is probable that they will reproduce the long-term labour energy accumulation pattern of the previous generation, by fostering pre-productive children.

For a decade, the Governement of Sierra Leone's top priority is to attract foreign investors into the agricultural sector (Baxter 2011; MAFFS 2009, 34). The choice is justified by the will to replace poor "traditional" peasant agriculture by modern contract farming and agroindustrial factory jobs. With several large agro-industrial units, notably palm plantations and mechanised sugar dedicated to ethanol production, planned or currently in operation, this policy bear fruits. But, unlike artisanal gold or diamond mining, palm oil extraction or mechanised sugar cane cropping are not generally generating large amount of jobs (Li 2011, Cochet 2014). As such, marginalised peasantries of Sierra Leone, like many in the 
contemporary rural South but unlike those in industrial countries, experience a kind of enclosures without jobs, that will lead to further impoverishment. Despite post-war double digit growth rate, this development model condemned any form of sustainable agricultural development and has proved to induce social and economical exclusion for the rural (or of recent rural origins) youth of the country that may undermine a fragile peace.

For the vast majority of youth in the villages the alternative will to be tied in manipulated "traditional" social relations in large domestic groups dominated by elders or to face precarious living conditions in small domestic groups. In both cases they won't be able to enjoy their own productive capacity to build a better future for themselves. In an attempt to escape this alternative many will probably continue to increase the number of "hyper-mobile youth" (Chauveau and Richards 2008) of the diamond Districts in the Eastern Sierra Leone. If we do not observe the polarization of the peasantry in the chiefdom of Sella Limba, from a wider point of view, class differentiation take the form of regular provision of cheap workers ready to be exploited on a daily basis by local big men and national dealers of the mining sector that do not need to take charge of the labour force reproduction on the long term.

\section{Acknowledgments}

This research has benefited from the advice of Pr. Frédéric Landy (French Institute of Pondicherry). The authors would like to thank Alex Nathaniel Sabado of the Journal of Agrarian Change Editorial Office and the anonymous reviewers who provided valuable suggestions to improve the final version of this paper. We also thank Giorgios $\mathrm{G}$. Hadjivayanis and Salha Hamdani for their decisive assistance in editing this paper in proper English.

\section{References}

Alie, Joe A. D. 1990. A new history of Sierra Leone. London, Royaume-Uni: Macmillan.

Baxter, Joan. 2011. Understanding Land Investment Deals in Africa: Country Report, Sierra Leone. Oakland Institute.

Bernstein, Henry. 2010. Class Dynamics of Agrarian Change. Bloomfield, CT: Kumarian Press.

Binder, K. 1989. 'The Vicious Cricle of Hunger and Indebtedness. Analysis of the Farming System of South-East Bombali District. Sierra Leone'. Farming Systems Analysis. Wageningen: ICRA.

Bledsoe, C.H. 1989. 'Strategies of Child Fosterage among Mende Grannies in Sierra Leone'. In Reproduction and Social Organization in Sub-Saharan Africa, by Ron J. 
Lesthaeghe. Berkeley: University of California Press.

Chauveau, Jean-Pierre, and Paul Richards. 2008. 'West African Insurgencies in Agrarian Perspective: Côte d'Ivoire and Sierra Leone Compared'. Journal of Agrarian Change 8 (4): 515-552. doi:10.1111/j.1471-0366.2008.00179.x.

Cochet, Hubert. 2014. "Pression commerciales sur la terre : exclusions paysannes ou création d'emploi ?" In Les exclusions paysannes : quels impacts sur le marché international du travail ? Agence Française de Développement, Conférences et séminaires, 12 : 5363.

Cochet, Hubert. 2015. Comparative Agriculture. Dordrecht: Springer.

Collier, Paul. 2001. 'Economic Causes of Civil Conflict and Their Implications for Policy'. In Turbulent Peace, the Challenge of Managing International Conflict, eds C.A. Crocker, F.O. Hampson and P. Aall, 143-62. Washington, DC: United States Institute of Peace.

Delarue, J. 2007. Mise Au Point D’une Méthode D'évaluation Systémique D’impact Des Projets de Développement Agricole Sur Le Revenu Des Producteurs: Étude de Cas En Région Kpèlè (République de Guinée). PhD dissertation. Paris: AgroParisTech.

Deveneaux, Gustav Kashope. 1973. The political and social impact of the colony in the Northern Sierra Leone 1821-1896. Ann Arbor: University microfilms.

Finnegan, Ruth. 1965. Survey of the Limba people of northern Sierra Leone. HM Stationery Office.

Gomez y Paloma, Sergi, Szvetlana Acs, Silvia Saravia Matus, Alpha Lakoh, Michel Baudoin, Gisele Hites, and Frank Sammeth. 2012. Rural Poverty Reduction and Food Security: The Case of Smallholders in Sierra Leone. Joint Research Centre Report. Seville: European commission.

Goody, Esther N. 1982. Parenthood and social reproduction: fostering and occupational roles in West Africa. Cambridge: Cambridge University Press.

Grace, John. 1975. Domestic Slavery in West Africa with Particular Reference to the Sierra Leone Protectorate, 1896-1927. New-York: Barnes \& Noble.

Howard, Allen. 1977. Big Men, traders and chiefs: power, commerce, and spatial change in Sierra leone. Guinea Plain 1865-1895. PhD Dissertation, University of Wisconsin.

Isaac, Barry L., and Shelby R. Conrad. 1982. 'Child Fosterage among the Mende of Upper Bambara Chiefdom, Sierra Leone: Rural-Urban and Occupational Comparisons'. Ethnology 21 (3): 243-257.

Kaplan, R.D. 1994. 'The coming anarchy: how scarcity, crime, overpopulation and disease rapidly destroying the social fabric of our planet'. Atlantic Monthly, February: 44-76.

Laing, Alexander Gordon. 1825. Travels in the Timannee, Kooranko, and Soolima Countries, in Western Africa. London: John Murray.

Leach, Melissa. 1994. Rainforest Relations: Gender and Resource Use Among the Mende of Gola, Sierra Leone. Edinburgh: Edinburgh University Press.

Levi, John. 1975. African agriculture misunderstood: policy in Sierra Leone. Stanford: Stanford University, Food Research Institute.

Li, Tania Murray. 2011. 'Centering labor in the land grab debate'. The Journal of Peasant Studies 38 (2): 281-98. doi:10.1080/03066150.2011.559009. 
MAFFS. 2009. 'National Sustainable Agriculture Development Plan 2010-2030.Sierra Leone's Comprehensive African Agriculture Development Programme'. MAFFS.

Mazoyer, Marcel, and Laurence Roudart. 2006. A History of World Agriculture: From the Neolithic Age to the Current Crisis. London: Earthscan.

McCulloch, M. 1950. The Peoples of Sierra Leone Protectorate. London: Forde. International African Institute.

Meillassoux, Claude. 1973. 'The Social Organisation of the Peasantry: The Economic Basis of Kinship'. The Journal of Peasant Studies 1 (1): 81-90. 1975. L'Esclavage en Afrique précoloniale. Paris: Maspéro.

-1981. Maidens, Meal and Money: Capitalism and the Domestic Community. Cambridge: Cambridge University Press.

. 1991. The Anthropology of Slavery: The Womb of Iron and Gold. Chicago: University of Chicago Press.

Palliere, Augustin. 2014. “”An Empty Bag Cannot Stand Upright ”. Local Agrarian Dynamics and Marginalisation of the Peasantry in Sierra Leone.' PhD dissertation. Paris: Université Paris Ouest Nanterre La Défense.

Paul, Jean-Luc. 2003. Anthropologie historique des Hautes Terres de Tanzanie orientale: Stratégies de peuplement et reproduction sociale chez les Luguru matrilinéaires. Paris: Karthala.

Peters, Krijn. 2006. Footpaths to reintegration: armed conflict, youth and the rural crisis in Sierra Leone. PhD Dissertation, Technology and Agrarian Development Group, Wageningen University.

Rashid, Ismail. 2009. 'Decolonization and Popular Contestation in Sierra Leone: The Peasant War of 1955-1956'. Afrika Zamani 17: 15-44.

Rey, Pierre-Philippe. 1979. 'Class contradiction in lineage societies'. Critique of Anthropology, 4 (13-14): 41-60.

Richards, Paul. 1983. 'Ecological Change and the Politics of African Land Use'. African Studies Review 26 (2): 1-72. doi:10.2307/524173.

- 1996. Fighting for the Rain Forest: War, Youth \& Resources in Sierra Leone. The International African Institute, James Currey.

Riddell, J. Barry. 1970. The Spatial Dynamics of Modernization in Sierra Leone: Structure, Diffusion, and Response. Northwestern University Press Evanston.

Sibanda, M. J. M. 1979. 'Dependency and Underdevelopment in Northwestern Sierra Leone, 1896-1939'. African Affairs 78 (313): 481-492.

Sierra Leone Gouvernment. 1956. Statement of the Sierra Leone Government on the Report of the Commission of Inquiry into Disturbances in the Protectorate (November, 1955 to March, 1956). Government of Sierra Leone Printer.

Swindell, Kenneth. 1974. 'Sierra Leonean Mining Migrants, Their Composition and Origins'. Transactions of the Institute of British Geographers, 47-64.

Tchaianov, Aleksandr Vasilievitch. 1966. On the theory of peasant economy. The American economic Association.

Zack-Williams, A. B. 1982. 'Merchant Capital and Underdevelopment in Sierra Leone'. Review of African Political Economy, 25, 74-82. doi:10.2307/3998098. 